\title{
Shattered Rails, Ruined Credit: Financial Fragility and Railroad Operations in the Great Depression
}

\author{
Daniel A. Schiffman* \\ February 2001
}

\begin{abstract}
*Department of Economics, Bar Ilan University, Ramat Gan, Israel 52900. schiffd@mail.biu.ac.il . I am indebted to the following for useful comments and suggestions: Charles Calomiris, Charles Himmelberg, Glenn Hubbard, Ben Broadbent, Michael Riordan, Mitali Das, Ronald Miller, Alessandra Casella, Philip Lane, Elise Brezis, and Arye Hillman. I also thank seminar participants at Bar Ilan, Columbia, the NBER Summer Institute 1998 and the Cliometrics Conference 1998. Joseph Mason graciously provided me with data on Reconstruction Finance Corporation loans to railroads, and helped me to locate additional data in the National Archives. The usual disclaimer applies.
\end{abstract}




\title{
Shattered Rails, Ruined Credit: Financial Fragility and Railroad Operations in the Great Depression \\ Daniel A. Schiffman \\ Bar Ilan University
}

February 2001

\begin{abstract}
The theory of "financial fragility" emphasizes the role of weak balance sheets in propagating and magnifying macroeconomic shocks. I use a new panel dataset to investigate the relationship between financial fragility and real activity on U.S. railroads during 1929-1940. First, I formulate a flexible accelerator model of maintenance expenditures and employment. Then, using the model as a benchmark, I ask whether a firm's degree of leverage, bankruptcy status, and size affect the responses of employment and maintenance expenditures to changes in operating revenues.
\end{abstract}

My results provide strong support for the predictions of the financial fragility theory. Leverage and bankruptcy status had the greatest effect during the worst years of the Depression and their impact differed systematically by firm size. Firm leverage had a large negative effect and generally affected small firms only. That is, firms whose fixed interest burdens were heavier than average exhibited lower than average annual growth in maintenance and employment; in general, this was true of small firms only. Bankruptcy effects were large and positive, and were present in large firms only. In other words, large firms that were in bankruptcy exhibited higher annual growth in maintenance and employment. Various categories of maintenance expenditure were not equally sensitive to financial effects; I find that highly indebted firms mainly used track maintenance to absorb revenue shocks.

The U.S. Government attempted to keep the railroads out of bankruptcy through loans from the Reconstruction Finance Corporation. I conclude that this policy was counterproductive.

JEL Classifications: E22, N12, N72, N22 


\section{Introduction}

The Great Depression confronts macroeconomists with the puzzle of a "massive monetary nonneutrality" (Bernanke and James 1991). Why were falling prices accompanied by severe and protracted falls in output?

The idea of "debt-deflation" originated with Irving Fisher (1933), who argued that depressions occurred only when two factors were combined: Deflation and high preexisting debts. What is the connection? As explained by Bernanke and James (1991),

By increasing the real value of nominal debts and promoting insolvency of borrowers, deflation creates an environment of financial distress in which the incentives of borrowers are distorted and in which it is difficult to extend new credit...the process of debt-deflation, that is, the increase in the real value of nominal debt obligations brought about by falling prices, erodes the net worth position of borrowers. A weakening financial position affects the borrower's actions (e.g. the firm may try to conserve financial capital by laying off workers or cutting back on investment) and also, by worsening the agency problems in the borrower-lender 
relationship, impairs access to new credit. Thus...financial distress can in principle impose deadweight losses on an economy, even if firms do not undergo liquidation.

In other words, (a) debt-deflation, financial distress, and lack of access to new credit are interrelated phenomena; (b) such conditions can cause severe damage to the economic system because they affect the decisions of firms with respect to key real variables.

Do these propositions actually reflect what happened during the Great Depression? The theory has distinct cross-sectional implications. It predicts that the most distressed economic actors curtail their activities most. Therefore, the best way to test the debt-deflation / financial fragility hypothesis is to examine the behavior of firms or consumers using microdata. While several studies have presented macroeconomic evidence in favor of the debt-deflation hypothesis (Mishkin 1978, Bernanke 1983, and Bernanke and James 1991), little direct microeconomic evidence is available. As Hubbard (1998) points out,

Historical case studies offer potentially valuable laboratories to study the role played by low or declining levels of net worth - often from 
periods of debt-deflation nationally or in certain sectors-in explaining low or declining investment. Those episodes do not, however, generally make available detailed firm-level data with which to examine implications of asymmetric information and incentive models.

For the Great Depression era, there are two important exceptions to this generalization: Hunter (1982) and Calomiris and Hubbard (1995). Hunter (1982) compares the cash management behavior of large and small firms. She finds that over 1938-1941, the largest $10 \%$ of firms maintained cash-to-receipts ratios at historically high levels, while the other $90 \%$ of firms maintained historically low cash-to-receipts ratios. Her interpretation is that corporate liquidity preference was very high during the period, but only the top $10 \%$ of firms were able to increase their cash holdings to the desired level. The other $90 \%$ could not do so because they depended on bank credit and were hit hard by policy-induced credit crunches.

Calomiris and Hubbard (1995) examine fixed investment behavior in 1936 and find that, for firms which faced a high external finance premium, investment was sensitive to the availability of internal funds. They see this evidence as 
supportive of Bernanke's view that the high cost of credit delayed the recovery from the Depression.

These studies support the proposition that the state of the balance sheet determined how economic actors responded to the economic environment of the late 1930's. But due to a lack of appropriate data, they cannot draw definitive conclusions for the critical 1929-1933 period.

This paper uses a new micro dataset to test for the effects of financial fragility on U.S. railroads during the period 1929-1940. The data are annual and include firm-level records of track and equipment maintenance as well as employment. By combining a rich dataset with ample quantitative and qualitative evidence, we can begin to fill the void in the literature that has been noted by Hubbard.

Using a simple accelerator model to construct neoclassical levels of warranted maintenance and employment, I find that firm leverage and bankruptcy status had a substantial influences on track maintenance, equipment maintenance and employment decisions. Leverage effects were highly negative, while the resolution of financial distress through bankruptcy had a highly positive effect. Furthermore, I find that leverage effects were much more pronounced for small firms, while bankruptcy effects mattered in large firms only. Lastly, the 
federal government's loans to distressed railroads failed to stimulate maintenance and employment. By preventing these railroads from entering bankruptcy, federal actions effectively reduced maintenance and employment.

The paper proceeds as follows: Section II provides a brief description of railroad operations and finances. Qualitative evidence is cited in order to demonstrate that heavily indebted roads used maintenance of way to absorb shocks to revenues. Section III develops a simple neoclassical model of maintenance, and derives an estimating equation that can be used to test for leverage and bankruptcy effects. Section IV describes the data and presents the estimation results, and Section V concludes.

\section{Railroad Operations, Financial Structure, and the Great Depression}

Historically, railroads have been the most failure-prone sector in the U.S. economy. Over 1,100 railroad bankruptcies occurred from 1876-1970 (Altman 1970). ${ }^{1} \quad$ Every major depression was accompanied by a wave of railroad bankruptcies; the worst of these waves coincided with the Great Depression. By 1938, one-third of U.S. railway mileage was operated by bankrupt firms (see Figure 1). This miserable record resulted from the combination of highly inflexible cost and debt structures with extreme sensitivity to the business cycle.

\footnotetext{
${ }^{1}$ This figure includes repeated bankruptcy episodes within the same firm.
} 
Here I present a brief description of railroad operations and financing in the interwar period, and the interplay between them during the Depression. ${ }^{2}$

Railroad operations were characterized by (a) high fixed costs and economies of scale; (b) a highly cyclical pattern of revenues and profits; (c) sticky wages that were set by collective bargaining (labor costs accounted for nearly $60 \%$ of operating costs); ${ }^{3}$ and (d) regulation by the Interstate Commerce Commission (ICC). As the Depression deepened, the railroads appealed to the ICC for permission to increase rates and cancel unprofitable trains. For the most part, the ICC refused to grant its approval.

Railroad financial policies were characterized by (a) an emphasis on debt instruments over equity. In other words, the industry maintained a high debt to capital ratio and incurred heavy fixed charges; ${ }^{4}(\mathrm{~b})$ insignificant holdings of cash and low corporate savings, which meant that fixed charges had to be paid out of current earnings; and (c) a failure (on the part of most firms) to plan for the retirement of maturing bond issues, on the assumption that they could simply be refinanced. With fixed charges holding steady, there existed an inverse relationship between revenues and the ratio of fixed charges to revenues. From

\footnotetext{
${ }^{2}$ For further details and more extensive statistical documentation, see Schiffman (2001b).

${ }^{3}$ Wage stickiness was not unique to the railroad sector. There were no significant wage cuts in manufacturing industry until October 1931. O'Brien (1989) attempts to explain why business avoided making wage cuts despite severe price deflation.

${ }^{4}$ These consisted primarily of interest on bonds and rent for leased lines.
} 
1929 to 1933, revenues fell 50.8\%; at the same time, the ratio of interest payments to revenues rose from $9.1 \%$ to $18.8 \%$ (see Figure 2) .

The theory of optimal structure predicts that railroads, whose profitability was so highly cyclical, should have maintained low debt to capital structures (Altman 1970). Schiffman (2001a) shows that heavy reliance on debt finance emerged in the $19^{\text {th }}$ Century as an equilibrium response to financial market frictions. Beginning in 1885, new factors came into play, reinforcing the tendency toward debt-heavy capital structures. These findings prove to be very useful in interpreting the results of Section IV: Cross-sectional differences in fixed charges can be regarded as predetermined with respect to our sample period.

Another important feature of the financial environment was that many states maintained a "legal list of investments" for banks and trusts. Since many institutional investors operated in New York, its legal list was very influential in the financial community. New York's legal list included railroad bonds, as long as they met the following condition: The issuing firm had to have covered fixed charges by 1.5 times in the previous year and in five of the previous six years. In 1932, the state was forced to relax this requirement as a concession to reality (see Figure 3); from then on, only railroads in default were excluded. A number of states also stipulated a minimum firm size or scale of operation. In 1929, the 
smallest $36 \%$ of firms failed to meet the size requirements of New York and New Jersey (author's calculation). The institution of the legal list contributed to major selloffs of railroad bonds and a massive collapse in their prices. In 1931 and 1932, only the very strongest railroads were able to refinance maturing bond issues.

Typically, financially troubled railroads resorted to short term credit from banks. The availability of bank credit declined drastically during the early 1930 's, as the banks were under tremendous pressure to increase the safety and liquidity of their assets (Calomiris and Wilson 1998). Banks refused to make new loans and called in many outstanding loans.

Faced with severe declines in revenues and (before interest) earnings, high fixed charges, and insufficient (or nonexistent) access to credit, distressed roads scrambled to find an internal source of "credit" which would save them from bankruptcy. There is strong anecdotal evidence that firms borrowed from the future by deferring routine maintenance activities. In the short term, this could be done without impairing safety. But firms knew that in the long run, varying maintenance according to the availability of cash was a costly policy indeed. Prior to the Depression, just over one-half of their workers were engaged in maintenance work. Unstable employment led to human capital deterioration and 
low morale. During slack periods, machines were idle, while materials had to be stored until maintenance work picked up again.

During the 1920's, the industry came to recognize the efficiency costs of sharp fluctuations in maintenance activity. A number of major roads, together with their unions, agreed on formal programs to stabilize employment. But, sensible as they were, these commitments eventually gave way in the face of the Depression.

Figure 4 shows the evolution of important real variables within the railroad sector, over the period 1927-1940. It is easily seen that maintenance of way declined by more than ton-miles (a measure of physical utilization of the road), and also declined by more than maintenance of equipment. How do we explain this fact? Contemporary observers of the railroad sector noted that managers, when they found themselves short of cash, preferred to cut maintenance of way (track and structures) rather than maintenance of equipment. This was because (a) the ICC conducted inspections and could legally order a road to remove bad order equipment from service; (b) equipment finance contracts stipulated that each car and locomotive be kept in good condition; (c) customers could refuse to patronize a railroad whose equipment appeared to be in bad shape. ${ }^{5}$

\footnotetext{
5 On the other hand, deteriorated sections of track were often located far from the eyes of customers. While passengers might notice an unmaintained track, passenger operations accounted for under $11.6 \%$ of revenues during 1929-1940.
} 
In 1931, The Federal government became greatly alarmed by developments in the railroad sector. Railroad bonds comprised $20 \%$ of the corporate bond market, and approximately the same percentage of total assets held by banks and insurance companies. It was feared that a wave of railroad defaults would exacerbate what was already a crisis in the banking and insurance sectors. In January 1932, the government formed the Reconstruction Finance Corporation (RFC) to provide loans to banks and railroads which were unable to obtain private credit. It was explicitly stated that these loans were intended to stimulate maintenance and employment. The RFC railroad program was controversial; many railroads succumbed to receivership (bankruptcy) despite RFC credit. ${ }^{6}$

Firms in bankruptcy were almost never liquidated. Operations continued under the direction of court-appointed receivers. To help them meet the firm's immediate obligations, the court authorized the issue of "receivers' certificates," which were senior to preexisting debts. Meanwhile, the firm's stakeholders worked out a reorganization plan; this was a lengthy, costly and complex process. According to contemporary analysts, receivers generally boosted maintenance expenditures in order to rehabilitate the road and prepare it to emerge from receivership.

\footnotetext{
${ }^{6}$ Some argued that the RFC had simply been too stingy with these roads, lending too little money at excessively high interest rates, against the best collateral the road could offer.
} 
To summarize our story, railroad firms had strong incentives to regularize maintenance and employment, but they chose not to do so due to financial considerations. Therefore, we expect to find that, ceteris paribus, financially strong railroads continued maintenance projects even during downturns and laid off fewer workers than did weak railroads. We expect to find a similar pattern when comparing large firms to small firms, since large firms generally have easier access to credit. (Large firms are better known and more established as borrowers, so asymmetric information problems are not as serious as they are for small firms.) We also expect bankrupt firms to spend more on maintenance and employ more workers work than nonbankrupt firms (ceteris paribus), since they are relatively free from the burden of fixed charges. The behavior of firms in bankruptcy may differ by firm size as well; large firms generally face greater difficulties and incur higher costs in renegotiating their debts with creditors (Gilson, John and Lang 1990). All of these differences among firms should be more pronounced during years of depression than during non-depression years: Revenue growth loosens credit constraints, so that if higher maintenance and employment are desired, these can readily be financed from the increase in operating revenues. We now turn to testing these important cross-sectional implications. 


\section{Testing for Financial Effects}

In order to test for financial effects, we need to compare actual maintenance decisions with an appropriate (financial effect-free) benchmark. I use the flexible accelerator model for this purpose. ${ }^{7}$ We begin with the familiar condition that in the long run, the marginal product of capital must equal the user cost of capital. This user cost is the sum of the expected real interest rate and the capital depreciation rate. In symbols, $M P K_{t}=r_{t}+\delta_{t}$. Suppose that (a) production is Cobb-Douglas and $\theta$ is the parameter associated with capital; (b) the firm faces an inverse demand curve of the form $P_{t}=\varepsilon_{t} Y_{t}^{-\eta}$, where $\varepsilon_{t}$ is an iid stochastic shock. Then $M P K_{t}=\theta(1-\eta)\left(S_{t} / K_{t}\right)$, where $S=$ sales revenue $=P Y$. Setting this equal to the long run MPK gives an expression for the optimal capital stock:

$$
K_{t}^{*}=\frac{\theta(1-\eta)}{r_{t}+\delta_{t}} S_{t}
$$

Assume further that capital is quasi-fixed; it can be varied, but subject to an adjustment cost. Therefore, the firm does not adjust $K$ to $K^{*}$ instantaneously; rather, it follows the partial adjustment rule

$$
\Delta \ln K_{t}=\lambda\left(\ln K_{t} *-\ln K_{t-1}\right)
$$

\footnotetext{
${ }^{7}$ Although the q theory of investment is preferred on theoretical grounds, it is well known that its empirical implementation is plagued by measurement problems and (often) poor results.
} 
where $\lambda$ is a parameter between zero and one. In other words, the actual change in the capital stock is a fraction $\lambda$ of the desired change. Substituting (1) into (2) yields the equation

$$
\Delta \ln K_{t}=\lambda \ln \theta(1-\eta)+\lambda \ln S_{t}-\lambda \ln K_{t-1}-\lambda \ln \left(r_{t}+\delta_{t}\right)
$$

This can be rewritten as

$$
\Delta \ln K_{t}=\lambda \ln \theta(1-\eta)+\lambda \Delta \ln S_{t}-\lambda\left(\ln K_{t-1}-\ln S_{t-1}\right)-\lambda \ln \left(r_{t}+\delta_{t}\right)
$$

We are almost ready to do some empirical work, but because $K$ cannot be observed directly, we need to rewrite (4) in terms of observables. Suppose that in the short run, the firm cannot invest in new capital, but it can expend resources to maintain existing capital. This activity adds to the effective capital stock $K$. At the same time, capital depreciates geometrically at a constant rate of $\delta$. In symbols, the accumulation equation is

$$
K_{t}=(1-\delta) K_{t-1}+M_{t}
$$

The stock of effective capital is constant if $M_{t}=\delta K_{t-1}$. The model has a steady state, which is defined by $\bar{M}=\delta \bar{K}, K_{t}=K_{t-1}=\bar{K}$. We loglinearize (5) around the steady state and use the resulting expression to substitute for $\ln \Delta K_{t}$ in terms of $\ln \Delta M_{t}$. We obtain an (approximate) equation of the form

$$
\begin{aligned}
\Delta \ln M_{t} & \approx \text { Constant }-\left(\ln M_{t-1}-\ln S_{t-1}\right)+(\lambda / \delta) \Delta \ln S_{t} \\
& -(\lambda / \delta) \ln r_{t}+(\delta-\lambda) \sum_{i=1}^{\infty}(1-\delta)^{i-1} \ln M_{t-i}
\end{aligned}
$$


The empirical work that follows is based on a flexible form of this specification. By being flexible, we obtain the best possible data description, which can then be used as a guide for a more sophisticated modeling approach. Although equation (6) implies explicit restrictions on the coefficients to be estimated, I do not impose them in practice. Based on the historical record, I allow the cost of capital to depend on leverage and bankruptcy status (yes or no). Furthermore, I permit $\lambda$ to (possibly) depend on firm size and on the state of the economy (whether in depression or not). In order to capture as much of the time series dynamics as possible, I include the lagged log difference of sales among the regressors, in addition to the error correction term $\left(\ln M_{t-1}-\ln S_{t-1}\right)$. Firm dummies are included to pick up differences in the elasticity of demand across firms. ${ }^{8}$ Time dummies are included to capture (as well as possible) the effects of productivity improvements in maintenance activities. Given that I have an annual panel dataset of finite time span, it is not possible to include an infinite number of lagged dependent variables in my regressions. Two lags of maintenance expenditures are a reasonable choice. The equations to be estimated are of the form

\footnotetext{
${ }^{8}$ Firms differed in the mix of commodities that they transported, the relative importance of passenger service within their overall business, and their exposure to competition from other modes of transportation.
} 


$$
\begin{aligned}
& \Delta \ln M_{i t}=\alpha_{i}+\gamma_{t}+\beta_{1} \Delta \ln S_{i t}+\beta_{2} \Delta \ln S_{i, t-1}+\beta_{3}\left(\ln M_{i, t-1}-\ln S_{i, t-1}\right) \\
& +\beta_{4} \ln M_{t-1}+\beta_{5} \ln M_{t-2}+\text { Finance Constraint Terms }+ \text { error }
\end{aligned}
$$

where $\mathrm{M}$ represents either maintenance of way or maintenance of equipment, $\mathrm{S}$ is operating revenue, $\alpha$ is a firm dummy and $\gamma$ is a time dummy.

As mentioned previously, maintenance was a highly labor intensive process; maintenance workers accounted for about one-half of total railroad employment. I do not model explicitly the connection between maintenance activity and demand for labor. However, I argue that employment should respond to the same variables as maintenance (both fundamental and financial), so that equation (7) can be expected to capture employment dynamics reasonably well. Therefore, (7) will be estimated for the following three dependent variables: Maintenance of way, maintenance of equipment, and employment.

\section{Data and Estimation Results}

My panel data set is collected from the Interstate Commerce Commission's Statistics of Railways, an annual publication (1927-1940 volumes). For each Class I railway, the ICC published a complete income account, balance sheet, operating averages and equipment in service. The reporting date is December 31. In addition, average employment and payroll expenditure figures were published 
beginning in $1927 .^{9}$ There were 174 active firms in 1927 ; this fell gradually to 133 in $1940 .^{10}$ After lags and differencing, I have 12 years of data for each firm (19291940), with some missing observations for firms which entered or exited during the sample period. ${ }^{11}$

Patterns of intercorporate ownership and control were notoriously complex. Some of the firms were subsidiaries of larger roads, and in some cases the parent railroad made intercorporate transfers each year to ensure that its subsidiary covered fixed charges exactly. The subsidiary often carried a large debt burden relative to operating revenues (over $45 \%$ in a good year, up to $90 \%$ in a bad year). Furthermore, subsidiaries were usually managed by the executives of the parent road. In such cases, the firm's own financial position was most probably irrelevant to its operating decisions. ${ }^{12}$

It is therefore necessary to classify firms by their degree of operational and financial independence. There are a number of ways to do this. In this paper, I follow the 1927 issue of SOR and classify as dependent any road which was part

\footnotetext{
${ }^{9}$ The annual employment numbers are averages of 12 mid-month counts.

${ }^{10}$ Firms exited through merger, being reclassified as Class II, or because their parent corporations began to report on a consolidated system basis (which eliminated individual reports by subsidiaries). Entry occurred through reclassification of firms formerly in Class II.

${ }^{11}$ The Western Maryland experienced a strike in 1933, and many operations were subcontracted out, so I deleted its employment observation for that year.

${ }^{12}$ There were some less obvious cases in which one railroad (call it Road A) would acquire significant holdings of stock in another railroad (Road B), in the hope that the properties would eventually be consolidated and operated as one. Although Road B's management remained intact,
} 
of a system headed by another road. I make two exceptions to this rule: the Louisville \& Nashville and the Texas \& New Orleans were so large that their financial status had to influence operating decisions, even if these were being made with the interests of the parent road in mind. Using these criteria, there were 92 independent roads in 1927. (This number rose to a maximum of 93 in 1928, and then fell gradually to 85 in 1940.) These roads comprised $82 \%$ of employment and operating revenues of all U.S. railroads (Classes I, II and III).

My first specification (Specification A) represents finance constraints simply as a function of leverage, measured as the lagged ratio of fixed charges to operating revenues. (See Appendix for details on the construction of this variable.) Examining the results for maintenance of way (Table 1), we see that leverage enters with a negative and significant coefficient of -.212 . This means that, everything else held constant, a firm whose lagged ratio of fixed charges to operating revenues was .1 above average saw maintenance of way grow by $2.12 \%$ per year less than an average firm. Leverage has no significant effect on equipment maintenance and employment (Tables 2 and 3). The flexible accelerator model, with its partial adjustment feature, performs quite well for all three dependent variables.

Specification B adds a receivership dummy, so that finance constraints depend on leverage and on receivership status. The effects of receivership on 
maintenance of way, maintenance of equipment and employment are $7.6 \%, 10.0 \%$ and $2.5 \%$ and are all highly significant. This conforms with our general intuition, but there are some surprises here: for maintenance of way, the leverage effect (for a firm whose lagged fixed charges/operating revenues is .1 above average) is $2.52 \%$ lower growth. Our (lagged) leverage measure averages .262 for firms in receivership (vs. .187 for firms that are not in receivership). Assuming that firms in receivership were completely freed from paying fixed charges, we multiply .262 by $-.252=-6.6 \%$. Adding this to $7.6 \%$ gives $1.0 \%$, but we cannot reject the hypothesis that this combination of coefficients is zero. It follows that we can attribute the entire effect of receivership to freedom from paying fixed charges. But this sensible result does not carry over to maintenance of equipment; the receivership effect of $10.0 \%$ per year is very large relative to the leverage effect of $-1.32 \%$ (significant at the $10 \%$ level). This implies that even after netting out the effect of being freed from fixed charges, bankruptcy raises maintenance of equipment growth by $6.6 \%$ per year. Repeating the calculation for employment, we find that the entire receivership effect can be attributed to freedom from paying fixed charges..$^{13}$

Road B's managers might even consult with A's managers on operating matters.

${ }^{13}$ It is also possible that firms significantly increase maintenance and employment upon emerging from receivership. Only seven firms leave receivership in the sample, of which four are independent operationally and financially. Preliminary regressions indicate a large positive effect on maintenance of way and employment, and a large negative effect on maintenance of equipment (all statistically significant). I plan to revisit this question in the future. 
Specification $\mathrm{C}$ is an asymmetric model--I permit the coefficient on leverage to vary across states of the economy (depression or nondepression, where 1930-1933 and 1938 are the depression years). For maintenance of way, leverage matters in both states (its effect is stronger during depression years), while for maintenance of equipment and employment, leverage matters only in depression years. We can calculate the leverage effect in depression years as the sum of the regular leverage coefficient and the special depression-year coefficient. For a firm whose lagged fixed charge/ operating revenue ratio was .1 above average, the depression-year leverage effect is estimated as $-4.1 \%$, (maintenance of way), $-2.2 \%$ (maintenance of equipment), and $-1.1 \%$ (employment). These results support the hypothesis that management had more freedom to reduce maintenance of way than to reduce maintenance of equipment. Employment was even less flexible; its estimated elasticity with respect to operating revenues is much lower than the corresponding elasticities for maintenance of way and maintenance of equipment.

Receiverships are likely to have asymmetric effects as well; Specification D tests for this. This hypothesis turns out to be true for maintenance of way and employment: the receivership effects on maintenance of way are $5.2 \%$ (nondepression) and $12.2 \%$ (depression), both of which are significant. For 
employment, the receivership effect is not significantly different from zero in nondepression years, and is $5.1 \%$ and significant in depression years. The receivership effect for maintenance of equipment is not asymmetric; it is estimated as $9.1 \%$ in nondepression years and $11.8 \%$ during depression years (both are significantly different from zero, but the estimated difference of $11.8 \%$ $9.1 \%=2.7 \%$ is not). This is somewhat surprising, given that the burden of fixed charges has no significant effect in nondepression years.

As a final exercise, I split the sample into large and small firms, using operating revenues of $\$ 6$ million as the cutoff point, and reestimate Specification D for the two subsamples. This sample split reveals major distinctions between large and small firms. The maintenance of way decisions of large firms were completely unaffected by leverage. Maintenance of equipment shows a significant leverage effect of $-2.8 \%$ in nondepression years, while employment shows a significant leverage effect in depression years only $(-2.4 \%$, for a firm whose lagged fixed charge to operating revenue ratio was .1 above average). But for small firms, maintenance of way was dramatically affected by leverage. The effect is estimated at $-2.1 \%$ in nondepression years, and a large $-5.7 \%$ in depression years (again, assuming that the firm had a lagged ratio of fixed charges to operating revenues that was .1 above average). For maintenance of equipment, I find a 
leverage effect of $-3.4 \%$ in depression years. There is a small depression-year leverage effect on employment in small firms $(-1.2 \%$, barely significant at the $10 \%$ level). This is half the leverage effect on employment in large firms. From anecdotal evidence, it seems that managers of small firms felt a greater personal connection with their employees and hesitated to fire them, even in the face of the worst business conditions.

Comparing receivership effects across subsamples reveals a striking pattern: Only large firms are affected by receivership status. For maintenance of way and employment, the effects are asymmetric; for maintenance of equipment, we cannot reject the null hypothesis of symmetry. Comparing large bankrupt firms to large nonbankrupt firms, I find that maintenance of way growth in bankrupt firms was 7.9\% higher in nondepression years, and a huge $16.0 \%$ higher in depression years. Employment growth in bankrupt firms was $2.8 \%$ higher in nondepression years, and $6.5 \%$ higher in depression years. The receivership effect for maintenance of equipment growth in large firms is estimated at $10.4 \%$ in nondepression years and $15.4 \%$ in depression years (the difference $15.4 \%-10.4 \%$ $=5.0 \%$ is not statistically significant).

Why do the effects of receivership depend so critically on size? It is possible to suggest that large firms had greater influence over judges and 
legislators, which they used to tilt the bankruptcy process in their favor. There is no explicit evidence in favor of this proposition. ${ }^{14}$ Furthermore, in a study of RFC assistance to banks, Mason (1996) demonstrates that "politics did not play a role in the allocation of RFC assistance." It is hard to imagine that politicians would meddle in the bankruptcy process while passing up the opportunity to meddle in the RFC's programs.

The most plausible explanation is that the large firms suffered from diseconomies of scale while in financial distress (and nonbankrupt); on the other hand, they enjoyed significant economies of scale in bankruptcy. Because large firms tended to have complex capital structures with many types of securities, it was more costly for them to renegotiate their debt service obligations (Gilson, John and Lang 1990). It was not unusual for large railroads to have more than ten different debt securities outstanding, in addition to common and preferred stock..$^{15}$ Large roads in distress found it easier to borrow more money than to renegotiate with multiple creditor groups. ${ }^{16}$

\footnotetext{
${ }^{14}$ If the proposition were true, one would expect small firms to complain of unfair treatment by the courts. I have found no mention of such complaints in any public document.

${ }^{15}$ This can be seen easily by leafing through a railroad manual (Moody's or Poor's).

${ }^{16}$ Congress came to recognize this problem, and attempted to address it by means of legislation. To reduce the incidence of bankruptcy, the federal bankruptcy law of 1933 provided for judicial readjustments of debt in nonbankrupt firms. The Baltimore and Ohio avoided bankruptcy in the late 1930's by taking advantage of this procedure. However, there were no other major "success stories" in that period; the new provision failed to stem the tide of bankruptcies.
} 
Warner (1977) finds significant economies of scale in bankruptcy. Using a sample of eleven railroad bankruptcy episodes (with beginning dates from 1933 to 1955), he measures direct bankruptcy costs, which are costs attributable to the court proceedings themselves. ${ }^{17}$ He finds that the ratio of bankruptcy costs to pre-bankruptcy market value was (significantly) negatively correlated with the pre-bankruptcy market value. He concludes that "there are substantial fixed costs associated with the bankruptcy process, and hence economies of scale with respect to bankruptcy costs." This explains why I find no significant bankruptcy effect for small firms. Direct costs consumed financial resources, which would otherwise have been spent on maintenance.

The Government's main weapon in the railroad crisis was the RFC. It made loans for the stated purpose of stimulating maintenance and employment. Was this goal accomplished? In light of the evidence just presented, it seems that RFC loans were a poor solution. They did not reduce the debt burden of the borrowers, and allowed them to avoid receivership. This outcome was precisely the opposite of what would have been desirable.

\footnotetext{
${ }^{17}$ The following are examples of indirect costs: (a) Customers decide to avoid doing business with a bankrupt firm, because they fear imminent default. (b) Managers fulfill their operating functions poorly because they are preoccupied by court proceedings. (c) Potential lenders restrict credit.
} 
In 1939, Herbert Spero published a book that was highly critical of the RFC railroad program. Based on case studies of large firms which borrowed from the RFC, Spero concluded that

While some reduction of maintenance and purchases of materials and supplies was justified by the loss of business, it was carried frequently to the point of undermaintenance and impaired the efficiency of transportation service. In many cases receivership and not RFC credits would have been a distinct aid to the economy. It would have put a halt to the drain of interest payments and the scrimping on various items in order to pay fixed charges. A step in the direction of a resumption of normal spending by the hard pressed lines would have been taken. Activity and employment would have been stimulated not only in the transportation field but in all those industries supplying the carriers with essentials.

In order to test Spero's hypothesis directly, I obtained the data for RFC loans and added the ratio (RFC Loan(t)/Fixed charges (t-1) ) to Specification D, allowing its effect to differ across states of the economy. ${ }^{18}$ RFC loans are insignificant for both maintenance categories, and are associated with a decline in 
employment. The median RFC loan (with RFC Loan(t)/Fixed charges (t-1) equal to 0.43 ) made a contribution to employment growth of $-0.94 \%$ per year. If bankrupt firms are removed from the sample, RFC loans become insignificant for all three dependent variables. Spero's intuition is thus confirmed.

These results are consistent with those of Mason (1996), who finds that RFC loans to banks in the 1930's were ineffective. ${ }^{19}$

\section{Conclusion}

The results in this paper provide strong support for the predictions of the financial fragility theory. As expected, leverage and bankruptcy status had asymmetric effects, which were greater during the worst years of the Depression. Also, leverage and bankruptcy effects differed systematically by firm size. Firm leverage had a large negative effect and generally affected small firms only. This is not surprising, since small firms generally find it more difficult to communicate information to the capital markets; this difficulty only intensifies during periods of crisis. Bankruptcy effects were large and positive, and were present in large firms only. This distinction can be explained by economies of scale in

18 The data come from the RFC's monthly reports to Congress, which can be found in the National Archives.

${ }^{19}$ According to Mason, “...The collateralized lending programs of the early RFC (February 1932March 1933) did not help banks endure the worst period of the Great Depression." However, “...The RFC preferred stock program utilized after March 1933 [which did not exist for railroads - DS] had beneficial effects on the survival of participating banks." 
bankruptcy, combined with diseconomies of scale in (nonbankrupt) states of financial distress. Various categories of maintenance expenditure were not equally sensitive to leverage; in highly indebted firms, reductions in track maintenance were the main mechanism for absorbing revenue shocks while avoiding default on interest payments. The methods of financing equipment, and other institutional constraints specific to the railroad sector, were responsible for this outcome. The final empirical result is that loans from the Reconstruction Finance Corporation failed to stimulate maintenance of way, maintenance of equipment and employment.

There are two major exceptions to the "theory-friendly" results just described. Why did large firms show a negative leverage effect on maintenance of equipment, in the "nondepression" years? Why did the same large firms show a negative leverage effect on employment during "depression years", which is larger and more significant than the corresponding effect in small firms? These apparent puzzles may be rooted in railroad-specific institutional factors, which I hope to address in future research. 


\section{References}

Altman, Edward (1970), "Predicting Railroad Bankruptcies in America," Bell Journal of Economics, 184-211.

Bernanke, Ben (1983), "Non-Monetary Effects of the Financial Crisis in the Propagation of the Great Depression," American Economic Review, 257-276.

Bernanke, Ben and Harold James (1991), "The Gold Standard, Deflation, and Financial Crisis in the Great Depression: An International Comparison," in R. Glenn Hubbard, ed., Financial Markets and Financial Crises. Chicago: University of Chicago Press, 33-68.

Calomiris, Charles W. and R. Glenn Hubbard (1995), "Internal Finance and Investment: Evidence from the Undistributed Profits Tax of 1936-37," Journal of Business, 443-482.

Calomiris, Charles W. and Berry Wilson (1998), "Bank Capital and Portfolio Management: The 1930's "Capital Crunch" and the Scramble to Shed Risk," NBER Working Paper \#6649.

Fisher, Irving (1933), "The Debt-Deflation Theory of Great Depressions," Econometrica, 337-357.

Gilson, Stuart C., Kose John and Larry H.P. Lang (1990), "Troubled Debt Restructurings," Journal of Financial Economics, pp. 315-353.

Hubbard, R. Glenn (1998), "Capital Market Imperfections and Investment," Journal of Economic Literature, 193-225. 
Hunter, Helen M. (1982), "The Role of Business Liquidity During the Great Depression and Afterwards: Differences Between Large and Small Firms," Journal of Economic History, 883-902.

Interstate Commerce Commission, various years, Statistics of Railways in the United States. Washington, DC: U.S. Government Printing Office.

Mason, Joseph R. (1996), The Determinants and Effects of Reconstruction Finance Corporation Assistance to Banks During the Great Depression. Ph.D. Dissertation, University of Illinois at Urbana-Champaign.

Mishkin, Frederic S. (1978), "The Household Balance Sheet and the Great Depression," Journal of Economic History, 918-937.

O'Brien, Anthony Patrick (1989), "A Behavioral Explanation for Nominal Wage Rigidity During the Great Depression," Quarterly Journal of Economics, 719-735.

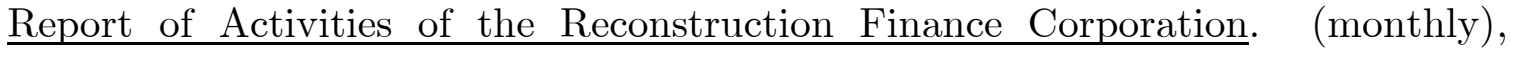
National Archives, Records of the Reconstruction Finance Corporation, various issues.

Schiffman (2001a), "Why Did Railroads Favor Debt Over Equity? The Evolution of Railroad Financing Choices, 1830-1929," Working Paper, Bar Ilan University.

Schiffman (2001b), "Willful Neglect and Self-Preservation: The Response of U.S. Railroads to the Great Depression," Working Paper, Bar Ilan University. 
Spero, Herbert (1939) Reconstruction Finance Corporation Loans to the Railroads, 1932-1937. Boston: Bankers Publishing Co.

Warner, Jerrold (1977), "Bankruptcy Costs: Some Evidence," Journal of Finance, 337-347. 
Figure 1

Railway Mileage in Receivership or Truteeship, as a Percentage of All Railway Mileage Operated, 1922-1940 (All U.S. Railways)

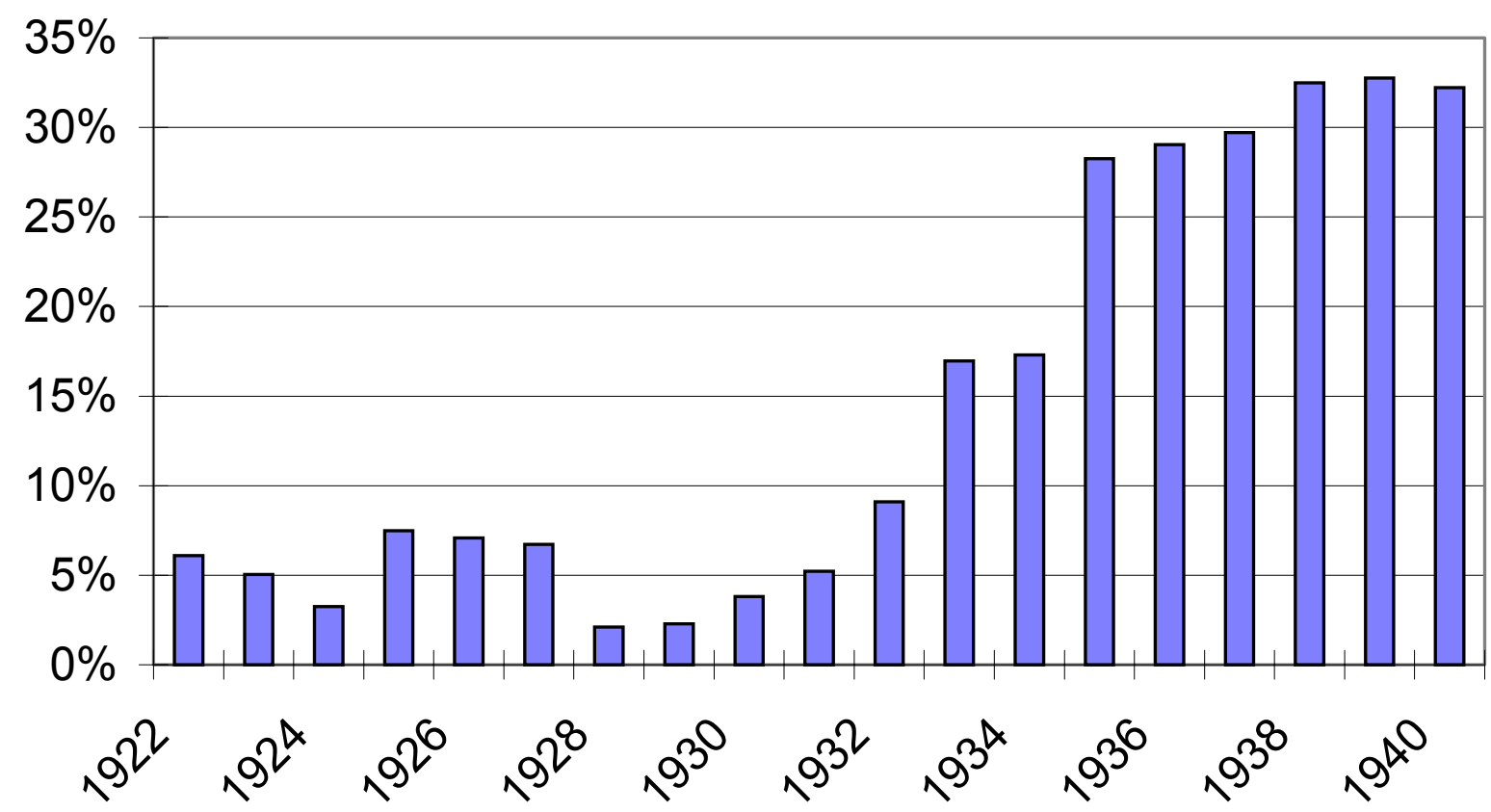


Figure 2

Interest Payments as a Percentage of Operating

Revenues, All U.S. Railroads, 1922-1940

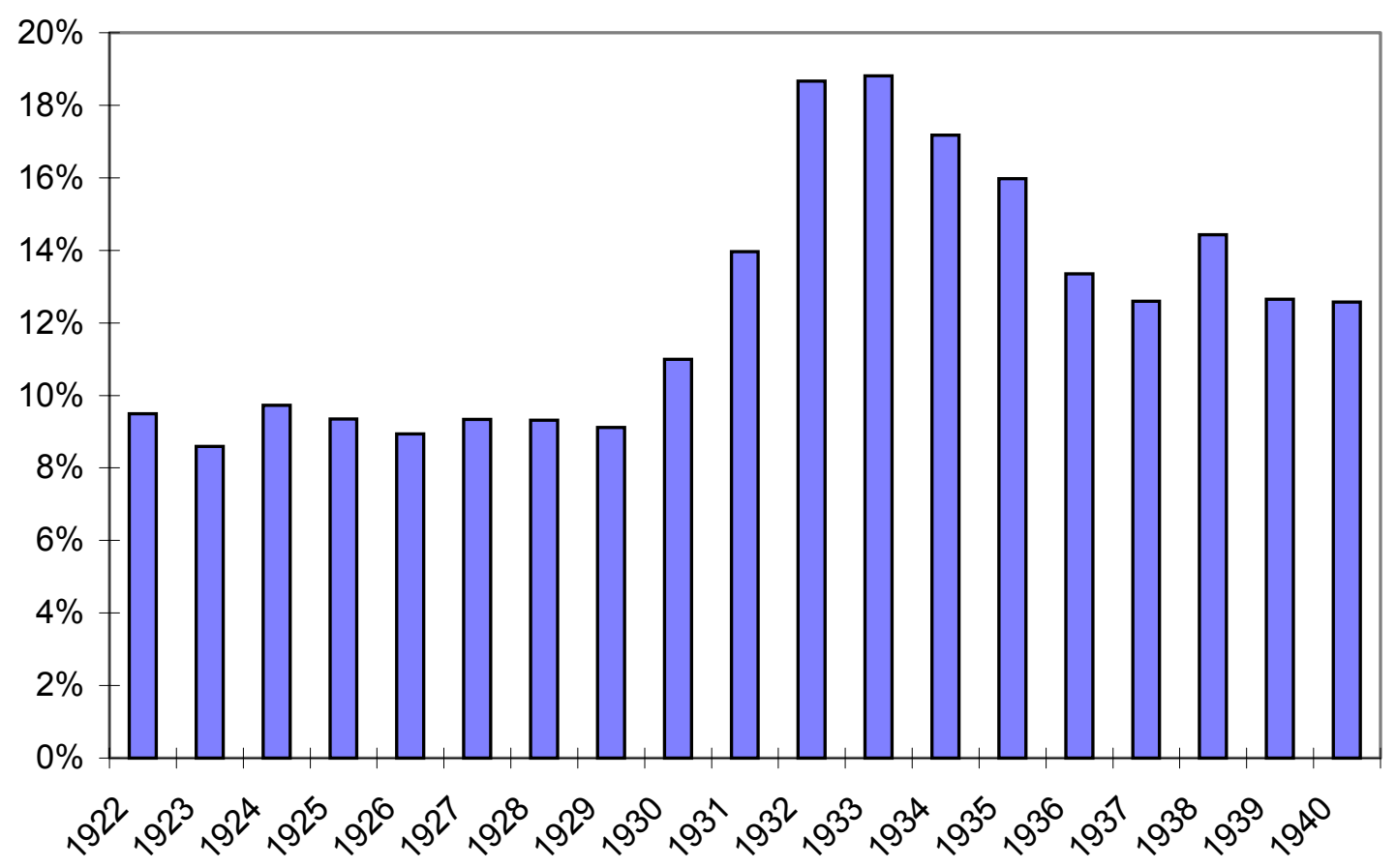


Figure 3

Times Fixed Charges Earned, Class I Railroads, 1925-1940

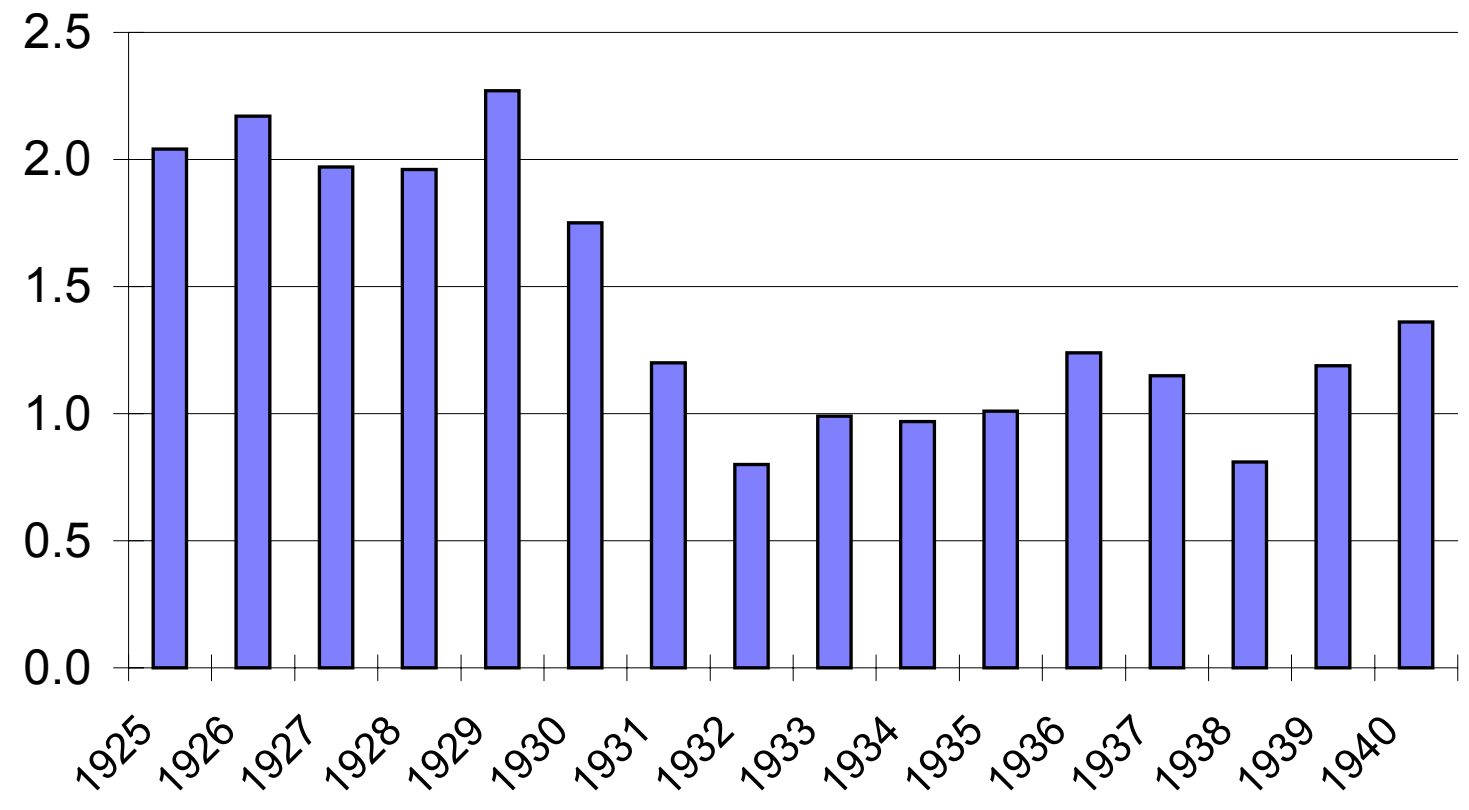


Figure 4

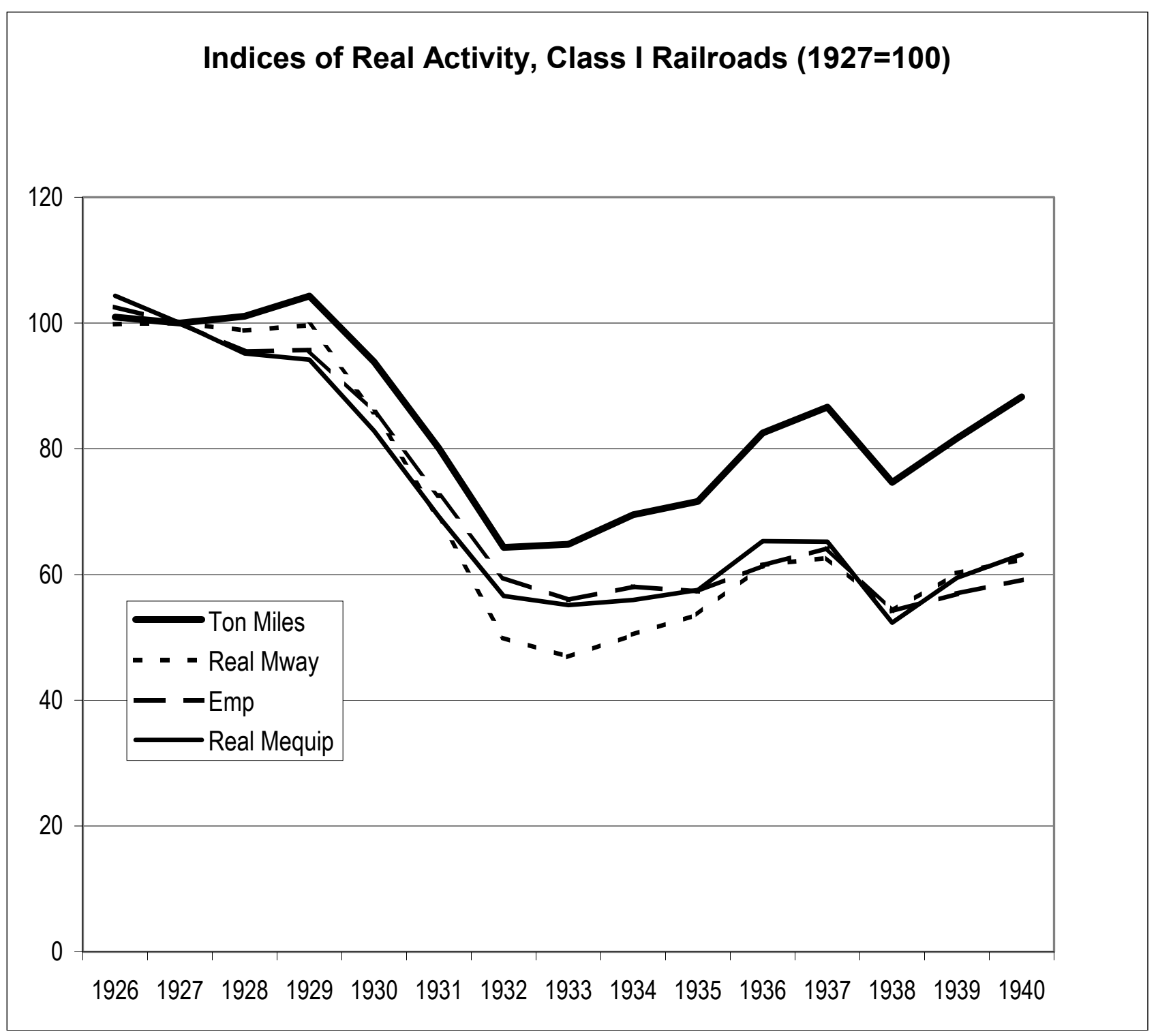




\section{Appendix: Construction of Data on Fixed Charges}

Prior to 1935, the ICC reported a statistic called "deductions from fixed charges." Beginning in 1935, the ICC reported "fixed charges," which is a slightly narrower category. For many firms, this creates the illusion of a drop in fixed obligations from 1934 to 1935. To adjust for this, I measure the ratio fixed charges / operating revenues in deviations from the mean, using two different means: One for 1927-34 and another for 1935-1940.

An examination of the histogram for fixed charges / operating revenues showed some outliers. Therefore, I truncated this variable at a minimum of 0 and a maximum of 1 . Only 5 observations were affected by this. 


\section{Table 1-Empirical Results, Maintenance of Way}

Firm dummies and year dummies were included in all specifications but are not reported. The sample consists of all independent firms, 1929-1940, except where noted otherwise. Large firms have operating revenues of over \$6,000,000. Depression years are 1930-33 and 1938. t-statistics appear in parentheses. ***Significant at the $1 \%$ level **Significant at the $5 \%$ level *Significant at the $10 \%$ level

\begin{tabular}{|c|c|c|c|c|c|c|}
\hline $\begin{array}{l}\text { Dependent Variable: } \\
\text { Maintenance of Way }\end{array}$ & A & B & $\mathrm{C}$ & $\begin{array}{l}\text { D } \\
\text { All indep. } \\
\text { firms }\end{array}$ & $\begin{array}{c}\mathrm{D} \\
\text { Large } \\
\text { Indep. } \\
\text { Firms }\end{array}$ & $\begin{array}{c}\mathrm{D} \\
\text { Small } \\
\text { Indep } \\
\text { Firms }\end{array}$ \\
\hline $\begin{array}{l}\text { Log difference of Operating } \\
\text { Revenues (t) }\end{array}$ & $\begin{array}{c}0.632^{* * *} \\
(20.26)\end{array}$ & $\begin{array}{c}0.642^{* * *} \\
(20.67)\end{array}$ & $\begin{array}{c}0.649^{* * *} \\
(20.93)\end{array}$ & $\begin{array}{c}0.646^{* * *} \\
(20.88)\end{array}$ & $\begin{array}{c}0.799^{* * *} \\
(16.11)\end{array}$ & $\begin{array}{c}0.653^{* * *} \\
(12.82)\end{array}$ \\
\hline $\begin{array}{l}\text { Log difference of Operating } \\
\text { Revenues }(\mathrm{t}-1)\end{array}$ & $\begin{array}{l}0.056 \\
(1.41)\end{array}$ & $\begin{array}{l}0.044 \\
(1.13)\end{array}$ & $\begin{array}{l}0.056 \\
(1.43)\end{array}$ & $\begin{array}{l}0.062 \\
(1.58)\end{array}$ & $\begin{array}{l}-0.007 \\
(-0.14)\end{array}$ & $\begin{array}{c}0.158^{* *} \\
(2.26)\end{array}$ \\
\hline $\begin{array}{l}\text { Log of dependent variable }(\mathrm{t}-1) \\
-\log \text { of operating revenues }(\mathrm{t}-1)\end{array}$ & $\begin{array}{c}-2.242^{* * *} \\
(-9.90)\end{array}$ & $\begin{array}{c}-2.372^{* * *} \\
(-10.45)\end{array}$ & $\begin{array}{c}-2.350^{* * *} \\
(-10.39)\end{array}$ & $\begin{array}{c}-2.310^{* * *} \\
(-10.23)\end{array}$ & $\begin{array}{c}-3.543^{* * *} \\
(-9.98)\end{array}$ & $\begin{array}{c}-2.038^{* * *} \\
(-5.65)\end{array}$ \\
\hline Log of dependent variable $(\mathrm{t}-1)$ & $\begin{array}{c}-0.133^{* * *} \\
(-3.25)\end{array}$ & $\begin{array}{c}-0.126^{* * *} \\
(-3.11)\end{array}$ & $\begin{array}{c}-0.134^{* * *} \\
(-3.31)\end{array}$ & $\begin{array}{c}-0.141^{* * *} \\
(-3.49)\end{array}$ & $\begin{array}{l}0.007 \\
(0.14)\end{array}$ & $\begin{array}{c}-0.236^{* * *} \\
(-3.17)\end{array}$ \\
\hline Log of dependent variable (t-2) & $\begin{array}{l}0.034 \\
(1.06)\end{array}$ & $\begin{array}{l}0.033 \\
(1.03)\end{array}$ & $\begin{array}{l}0.045 \\
(1.40)\end{array}$ & $\begin{array}{l}0.053^{*} \\
(1.66)\end{array}$ & $\begin{array}{l}0.007 \\
(0.14)\end{array}$ & $\begin{array}{c}0.120^{* *} \\
(2.21)\end{array}$ \\
\hline $\begin{array}{l}\text { Fixed Charges (t-1) / Operating } \\
\text { Revenues (t-1) }\end{array}$ & $\begin{array}{c}-0.212^{* * *} \\
(-3.06) \\
\end{array}$ & $\begin{array}{c}-0.252^{* * *} \\
(-3.53) \\
\end{array}$ & $\begin{array}{c}-0.190^{* * *} \\
(-2.64) \\
\end{array}$ & $\begin{array}{c}-0.167^{* *} \\
(-2.30) \\
\end{array}$ & $\begin{array}{l}-0.132 \\
(-1.20) \\
\end{array}$ & $\begin{array}{l}-0.208^{*} \\
(-1.83) \\
\end{array}$ \\
\hline Receivership Dummy & & $\begin{array}{c}0.076^{* * *} \\
(3.92)\end{array}$ & $\begin{array}{c}0.075^{* * *} \\
(3.86)\end{array}$ & $\begin{array}{c}0.052^{* *} \\
(2.47)\end{array}$ & $\begin{array}{c}0.079^{* * *} \\
(3.89)\end{array}$ & $\begin{array}{l}0.019 \\
(0.32)\end{array}$ \\
\hline $\begin{array}{l}\text { Depression Dummy } \times \\
\text { Fixed Charges }(\mathrm{t}-1) / \text { Operating } \\
\text { Revenues }(\mathrm{t}-1)\end{array}$ & & & $\begin{array}{c}-0.217^{* * *} \\
(-3.00)\end{array}$ & $\begin{array}{c}-0.261^{* * *} \\
(-3.53)\end{array}$ & $\begin{array}{l}-0.000 \\
(-0.00)\end{array}$ & $\begin{array}{c}-0.365^{* * *} \\
(-3.19) \\
\end{array}$ \\
\hline $\begin{array}{l}\text { Depression Dummy } \times \\
\text { Receivership Dummy }\end{array}$ & & & & $\begin{array}{c}0.070^{* * *} \\
(2.64)\end{array}$ & $\begin{array}{c}0.082^{* * *} \\
(2.97)\end{array}$ & $\begin{array}{c}0.005 \\
(0.084)\end{array}$ \\
\hline Observations & 1044 & 1043 & 1043 & 1043 & 656 & 387 \\
\hline Adj. R-Sq. & 0.677 & 0.682 & 0.685 & 0.687 & 0.749 & 0.644 \\
\hline
\end{tabular}


Table 2-Empirical Results, Maintenance of Equipment

\begin{tabular}{|c|c|c|c|c|c|c|}
\hline $\begin{array}{l}\text { Dependent Variable: } \\
\text { Maintenance of } \\
\text { Equipment }\end{array}$ & $\mathrm{A}$ & B & $\mathrm{C}$ & $\begin{array}{l}\text { D } \\
\text { All indep. } \\
\text { firms }\end{array}$ & $\begin{array}{c}\text { D } \\
\text { Large } \\
\text { Indep. } \\
\text { Firms }\end{array}$ & $\begin{array}{c}\mathrm{D} \\
\text { Small } \\
\text { Indep } \\
\text { Firms }\end{array}$ \\
\hline $\begin{array}{l}\text { Log difference of Operating } \\
\text { Revenues (t) }\end{array}$ & $\begin{array}{c}0.559^{* * *} \\
(15.77)\end{array}$ & $\begin{array}{c}0.575^{* * *} \\
(16.30)\end{array}$ & $\begin{array}{c}0.579^{* * *} \\
(16.38)\end{array}$ & $\begin{array}{c}0.578^{* * *} \\
(16.33)\end{array}$ & $\begin{array}{c}0.753^{* * *} \\
(11.21)\end{array}$ & $\begin{array}{c}0.625^{* * *} \\
(12.67)\end{array}$ \\
\hline $\begin{array}{l}\text { Log difference of Operating } \\
\text { Revenues (t-1) }\end{array}$ & $\begin{array}{l}-0.004 \\
(-0.10)\end{array}$ & $\begin{array}{l}-0.021 \\
(-0.50)\end{array}$ & $\begin{array}{l}-0.016 \\
(-0.39)\end{array}$ & $\begin{array}{l}-0.016 \\
(-0.37)\end{array}$ & $\begin{array}{l}0.011 \\
(0.20)\end{array}$ & $\begin{array}{l}0.030 \\
(0.42)\end{array}$ \\
\hline $\begin{array}{l}\text { Log of dependent variable }(t-1) \\
-\log \text { of operating revenues }(t-1)\end{array}$ & $\begin{array}{c}-0.514^{* * *} \\
(-11.05) \\
\end{array}$ & $\begin{array}{c}-0.549^{* * *} \\
(-11.74) \\
\end{array}$ & $\begin{array}{c}-0.547^{* * *} \\
(-11.73) \\
\end{array}$ & $\begin{array}{c}-0.545^{* * *} \\
(-11.66) \\
\end{array}$ & $\begin{array}{c}-0.591^{* * *} \\
(-9.20)\end{array}$ & $\begin{array}{c}-0.609^{* * *} \\
(-7.92) \\
\end{array}$ \\
\hline Log of dependent variable $(\mathrm{t}-1)$ & $\begin{array}{c}-0.281^{* * *} \\
(-6.14) \\
\end{array}$ & $\begin{array}{c}-0.262^{* * *} \\
(-5.77) \\
\end{array}$ & $\begin{array}{c}-0.262^{* * *} \\
(-5.76) \\
\end{array}$ & $\begin{array}{c}-0.263^{* * *} \\
(-5.78) \\
\end{array}$ & $\begin{array}{c}-0.242^{* * *} \\
(-3.89) \\
\end{array}$ & $\begin{array}{c}-0.222^{* * *} \\
(-3.03) \\
\end{array}$ \\
\hline Log of dependent variable (t-2) & $\begin{array}{l}0.042 \\
(1.48)\end{array}$ & $\begin{array}{l}0.037 \\
(1.32)\end{array}$ & $\begin{array}{l}0.041 \\
(1.44)\end{array}$ & $\begin{array}{l}0.041 \\
(1.46)\end{array}$ & $\begin{array}{l}0.040 \\
(1.14)\end{array}$ & $\begin{array}{l}-0.012 \\
(-0.24)\end{array}$ \\
\hline $\begin{array}{l}\text { Fixed Charges (t-1) / Operating } \\
\text { Revenues }(\mathrm{t}-1)\end{array}$ & $\begin{array}{l}-0.086 \\
(-1.10) \\
\end{array}$ & $\begin{array}{l}-0.132^{*} \\
(-1.69)\end{array}$ & $\begin{array}{l}-0.097 \\
(-1.18) \\
\end{array}$ & $\begin{array}{l}-0.089 \\
(-1.08)\end{array}$ & $\begin{array}{l}-0.280^{*} \\
(-1.89)\end{array}$ & $\begin{array}{l}-0.101 \\
(-0.92) \\
\end{array}$ \\
\hline Receivership Dummy & & $\begin{array}{c}0.100^{* * *} \\
(4.53)\end{array}$ & $\begin{array}{c}0.099^{* * *} \\
(4.50)\end{array}$ & $\begin{array}{c}0.091^{* * *} \\
(3.75)\end{array}$ & $\begin{array}{c}0.104^{* * *} \\
(3.84)\end{array}$ & $\begin{array}{l}0.042 \\
(0.72)\end{array}$ \\
\hline $\begin{array}{l}\text { Depression Dummy } \times \\
\text { Fixed Charges }(\mathrm{t}-1) / \text { Operating } \\
\text { Revenues }(\mathrm{t}-1)\end{array}$ & & & $\begin{array}{l}-0.125 \\
(-1.51)\end{array}$ & $\begin{array}{l}-0.141^{*} \\
(-1.67)\end{array}$ & $\begin{array}{l}0.038 \\
(0.24)\end{array}$ & $\begin{array}{c}-0.238^{* *} \\
(-2.18)\end{array}$ \\
\hline $\begin{array}{l}\text { Depression Dummy } \times \\
\text { Receivership Dummy }\end{array}$ & & & & $\begin{array}{l}0.027 \\
(0.91)\end{array}$ & $\begin{array}{l}0.050 \\
(1.32)\end{array}$ & $\begin{array}{l}-0.022 \\
(-0.42)\end{array}$ \\
\hline Observations & 1044 & 1043 & 1043 & 1043 & 656 & 387 \\
\hline Adj. R-Sq. & 0.607 & 0.615 & 0.616 & 0.616 & 0.623 & 0.636 \\
\hline
\end{tabular}


Table 3-Empirical Results, Employment

\begin{tabular}{|c|c|c|c|c|c|c|}
\hline $\begin{array}{l}\text { Dependent Variable: } \\
\text { Employment }\end{array}$ & A & $\mathrm{B}$ & $\mathrm{C}$ & $\begin{array}{l}\text { D } \\
\text { All indep. } \\
\text { firms }\end{array}$ & $\begin{array}{c}\text { D } \\
\text { Large } \\
\text { Indep. } \\
\text { Firms }\end{array}$ & $\begin{array}{c}\text { D } \\
\text { Small } \\
\text { Indep } \\
\text { Firms }\end{array}$ \\
\hline $\begin{array}{l}\text { Log difference of Operating } \\
\text { Revenues }(\mathrm{t})\end{array}$ & $\begin{array}{c}0.242^{* * * *} \\
(13.82)\end{array}$ & $\begin{array}{c}0.245^{* * *} \\
(13.99)\end{array}$ & $\begin{array}{c}0.249^{* * *} \\
(14.19)\end{array}$ & $\begin{array}{c}0.248^{* * * *} \\
(14.12)\end{array}$ & $\begin{array}{c}0.546^{* * *} \\
(19.22)\end{array}$ & $\begin{array}{c}0.163^{* * *} \\
(6.46)\end{array}$ \\
\hline $\begin{array}{l}\text { Log difference of Operating } \\
\text { Revenues (t-1) }\end{array}$ & $\begin{array}{c}0.049^{* *} \\
(2.14)\end{array}$ & $\begin{array}{c}0.046^{* *} \\
(1.97)\end{array}$ & $\begin{array}{c}0.051^{* *} \\
(2.20)\end{array}$ & $\begin{array}{c}0.054^{* *} \\
(2.33)\end{array}$ & $\begin{array}{c}0.096^{* * *} \\
(3.40)\end{array}$ & $\begin{array}{l}0.036 \\
(0.97)\end{array}$ \\
\hline $\begin{array}{l}\text { Log of dependent variable }(t-1) \\
-\log \text { of operating revenues }(t-1)\end{array}$ & $\begin{array}{c}-0.122^{* * *} \\
(-4.96)\end{array}$ & $\begin{array}{c}-0.131^{* * *} \\
(-5.28)\end{array}$ & $\begin{array}{c}-0.131^{* * *} \\
(-5.31)\end{array}$ & $\begin{array}{c}-0.128^{* * *} \\
(-5.19)\end{array}$ & $\begin{array}{c}-0.235^{* * *} \\
(-7.79)\end{array}$ & $\begin{array}{c}-0.129^{* * *} \\
(-3.23)\end{array}$ \\
\hline Log of dependent variable $(\mathrm{t}-1)$ & $\begin{array}{c}-0.143^{* * *} \\
(-4.08)\end{array}$ & $\begin{array}{c}-0.140^{* * *} \\
(-4.01)\end{array}$ & $\begin{array}{c}-0.146^{* * *} \\
(-4.19)\end{array}$ & $\begin{array}{c}-0.153^{* * *} \\
(-4.39)\end{array}$ & $\begin{array}{c}-0.093^{* *} \\
(-2.32)\end{array}$ & $\begin{array}{c}-0.228^{* * *} \\
(-3.89)\end{array}$ \\
\hline Log of dependent variable (t-2) & $\begin{array}{l}-0.048 \\
(-1.50)\end{array}$ & $\begin{array}{l}-0.048 \\
(-1.49)\end{array}$ & $\begin{array}{l}-0.038 \\
(-1.19)\end{array}$ & $\begin{array}{l}-0.032 \\
(-0.99)\end{array}$ & $\begin{array}{l}0.039 \\
(1.03)\end{array}$ & $\begin{array}{c}-0.106^{* *} \\
(-2.01)\end{array}$ \\
\hline $\begin{array}{l}\text { Fixed Charges (t-1) / Operating } \\
\text { Revenues (t-1) }\end{array}$ & $\begin{array}{l}-0.030 \\
(-0.77)\end{array}$ & $\begin{array}{l}-0.041 \\
(-1.06)\end{array}$ & $\begin{array}{l}-0.013 \\
(-0.31)\end{array}$ & $\begin{array}{l}-0.001 \\
(-0.02)\end{array}$ & $\begin{array}{l}-0.055 \\
(-0.822)\end{array}$ & $\begin{array}{l}-0.048 \\
(-0.86)\end{array}$ \\
\hline Receivership Dummy & & $\begin{array}{c}0.025^{* *} \\
(2.23) \\
\end{array}$ & $\begin{array}{c}0.024^{* *} \\
(2.20)\end{array}$ & $\begin{array}{c}0.011 \\
(0.952) \\
\end{array}$ & $\begin{array}{c}0.028^{* *} \\
(2.42)\end{array}$ & $\begin{array}{l}-0.006 \\
(-0.19) \\
\end{array}$ \\
\hline $\begin{array}{l}\text { Depression Dummy } \times \\
\text { Fixed Charges }(\mathrm{t}-1) / \text { Operating } \\
\text { Revenues }(\mathrm{t}-1)\end{array}$ & & & $\begin{array}{c}-0.101^{* *} \\
(-2.45)\end{array}$ & $\begin{array}{c}-0.125^{* * *} \\
(-2.98)\end{array}$ & $\begin{array}{c}-0.181^{* * *} \\
(-2.73)\end{array}$ & $\begin{array}{l}-0.069 \\
(-1.22)\end{array}$ \\
\hline $\begin{array}{l}\text { Depression Dummy } \times \\
\text { Receivership Dummy }\end{array}$ & & & & $\begin{array}{c}0.040^{* * *} \\
(2.66)\end{array}$ & $\begin{array}{c}0.037^{* *} \\
(2.30)\end{array}$ & $\begin{array}{l}0.035 \\
(1.26)\end{array}$ \\
\hline Observations & 1041 & 1040 & 1040 & 1040 & 653 & 387 \\
\hline Adj. R-Sq. & 0.632 & 0.633 & 0.635 & 0.638 & 0.755 & 0.600 \\
\hline
\end{tabular}

